\title{
The stories scientists tell: narrative features in the scientific article of the late seventeenth and early twenty-first centuries
}

Quand les scientifiques racontent une histoire: traits narratifs dans l'article scientifique à la fin du XVII ${ }^{e}$ siècle et au début du XXI ${ }^{e}$ siècle

\section{David Banks}

\section{OpenEdition}

\section{Journals}

\section{Electronic version}

URL: http://journals.openedition.org/asp/4877

DOI: $10.4000 / a s p .4877$

ISSN: 2108-6354

\section{Publisher}

Groupe d'étude et de recherche en anglais de spécialité

\section{Printed version}

Date of publication: 1 November 2016

Number of pages: $27-47$

ISSN: 1246-8185

Electronic reference

David Banks, "The stories scientists tell: narrative features in the scientific article of the late seventeenth and early twenty-first centuries », ASp [Online], 70 | 2016, Online since 01 November 2017, connection on 02 November 2020. URL : http://journals.openedition.org/asp/4877 ; DOI : https://doi.org/10.4000/asp.4877

This text was automatically generated on 2 November 2020.

Tous droits réservés 


\title{
The stories scientists tell: narrative features in the scientific article of the late seventeenth and early twenty-first centuries
}

\author{
Quand les scientifiques racontent une histoire: traits narratifs dans l'article \\ scientifique à la fin du XVII ${ }^{e}$ siècle et au début du XXI ${ }^{e}$ siècle
}

David Banks

\section{Introduction}

1 In this paper, ${ }^{1}$ I would like to look at the question of the uses of narration in the scientific research article. I do not claim to be a specialist in narrativity theory, so when I use terms such as "narration" and "story-telling" I am using them in their nontechnical, ordinary language sense. Thompson claims that "relatively little research has been performed on the use of narrative in academic genres" (2002: 150), and I must admit that I would agree with this: my efforts to uncover literature on the subject have not been particularly fruitful. When Barthes produced an (admittedly open) list of genres containing récits (translated as "narrative" in the English version [Barthes 1977]), he came up with:

le mythe, la légende, la fable, le conte, la nouvelle, l'épopée, l'histoire, la tragédie, le drame, la comédie, la pantomime, le tableau peint (que l'on pense à la Sainte-Ursule de Carpaccio), le vitrail, le cinéma, les comics, le fait divers, la conversation. (Barthes 1966: 1)

2 but nothing remotely like the research article. What little there is on narration in science tends to be on popular science (Myers 1990), science education and textbooks (Halliday \& Martin 1993), the history of science (Kuukkanen 2012), or like Grobstein (2005) on the history of science in an educational context, oral presentations (Thompson 2002), or even medical advertisements (Oakley 2005), rather than the 
scientific research article as such. Among those that do touch on the question, Lewin et al. (2001) claim that there are narrative elements in describing previous research, but that this terminates "after the narrative arrives at present research" (2001: 59). Gross et al. (2002) and Atkinson (1999) argue that the nature of narrative in the scientific article has changed over time, the latter claiming that it has been gradually lost in the Philosophical Transactions, to the extent that "by 1975 what experimental narrative remained was usually highly circumscribed" (1999: 145). Since many of these authors write from a sociolinguistic rather than a text analysis point of view, it is probably not surprising that there is very little on the way narrative is encoded in the text. However, Myers (1990) and Czarniawska-Joerges (1995) point out the sequential nature of narrative. For Myers, narrative is

the selection and sequencing of events so that they have a subject, they form a coherent whole with a beginning and an end, and they have a meaning that is conveyed by the sequence as a whole. (Myers 1990: 102)

3 For Licoppe (1994), concerned with scientific writing in the late seventeenth century, narrative has the form " $\mathrm{X}$ did and $\mathrm{X}$ saw", where $\mathrm{X}$ is usually a pronoun. Atkinson (1999) gives, as features of narrative, past tense verbs, third-person pronouns, perfect aspect verbs, and verbs of communication. I will take it that narrative does involve a sequence of events, and that this will usually be indicated by a series of verbs, usually in the past tense, or with perfect aspect, and frequently with first or third-person pronouns. Temporal adverbials may also be involved in establishing the sequence.

4 I shall look at the question of story-telling in the scientific article at two points in time: first in the very earliest articles in the late seventeenth century, and then in very recent articles published in 2015-2016. The corpus for the late seventeenth century is taken from the Philosophical Transactions, and I shall start by giving the historical background in which this periodical was created. I shall attempt to identify examples of story-telling and discuss the functions that they fulfil. I shall then look at recent articles from the Proceedings of the Royal Society. This periodical is divided into two series, Series A dealing with mathematical, physical and engineering sciences, and Series B dealing with biological sciences. ${ }^{2}$ I shall take the Series A articles first, again identifying examples of narration and the functions they fulfil, and then do the same thing with the Series B articles. I shall discuss differences between the early and late articles, and also between the Series A and Series B articles.

\section{Philosophical Transactions - historical background}

5 If one wanted one word to describe seventeenth-century England, then the word chaos would be a prime contender. Charles I came to the throne in 1625 . His reign was marred by constant disputes with Parliament over two basic issues. The first was a question of finance: from whom could he raise taxes? On whose authority? How much? And so on. The second question was one of religion: Parliament was fiercely Protestant, while Charles himself had Catholic sympathies, and indeed the Queen, Henrietta, a sister of Louis XIII of France, was herself a Catholic, and consequently there were numerous Catholics at court. The bitterness of these disputes came to a head in 1642 with the outbreak of the Civil War. The war went on until 1649 when it ended with the capture, trial, and execution by beheading of Charles I. This was followed by a period of repressive, puritanical government under Cromwell. Cromwell died in 1658, and one 
must assume that he had dynastic aspirations, since he had arranged for his son, Richard, to succeed him. However, Richard did not share his father's lust for power, and after a few months resigned, leaving the way open for the Restoration of the monarchy. This eventually took place in 1660, with the return of Charles II (Clark 1956; Hill 1969; Kishlansky 1996).

61660 was also the year which saw the founding of the Royal Society. One of its secretaries was Henry Oldenburg. He had become the centre of a network of scientific correspondence, rather like Mersenne a little earlier in France. This correspondence was not made up of private letters in the modern sense. This type of correspondence was one of the ways of disseminating scientific information, and it was generally understood that these letters should be recopied, sent on, read at meetings, and so on (Gotti 2006, 2011). Most of the members of the Royal Society were virtuosi, or gentlemen scientists, who had private means. This, however, was not the case of Oldenburg, who had to earn his living, and his idea was to use his correspondence to create a scientific newsletter which he could sell to increase his meagre income. The first issue of his newsletter, entitled Philosophical Transactions came out on 6 March 1665 (Bluhm 1960; Hall 2002; Lyons 1944).

7 The period 1665 to 1700 is particularly significant in that the two main academic periodicals publishing in vernacular languages were founded in 1665. Two months before the first issue of Philosophical Transactions, the Journal des Sçavans appeared for the first time in Paris on 5 January 1665 (Morgan 1928). This French journal was founded by Denis de Sallo at the instigation of Colbert, whose object was to control new thought (Gignoux 1941). There were other periodicals, but they were generally shortlived, whereas these two publications both still exist (Kronick 1662, 1991). The Académie Royale des Sciences was founded in 1666, but in this initial period its results were not widely published. The publications which it did produce were lavish, luxurious books, which were technically the property of the king, Louis XIV, and he used them as gifts for illustrious guests. Otherwise they were difficult to obtain. The fact that the Académie Royale was a royal institution was felt to be sufficient justification in itself and obviated the need for wider distribution (Licoppe 1994, 1994). It was only in 1699 that the Académie Royale decided to change this, and to publish its Mémoires on a wider basis. The Mémoires for 1699 duly appeared, eventually, in 1702 (Hahn 1971; Hirschfield 1981; McClellan III 2001; Banks in press). So, from 1665 till the end of the century, the Journal des Sçavans and Philosophical Transactions held sway. The French journal was the first to appear and covered all disciplines, so can be said to be the first academic periodical; the English periodical covered only science and technology, so can claim to be the first truly scientific journal.

\section{The seventeenth-century corpus}

8 For the purpose of this study I have taken a small sample, or mini-corpus (Banks 2005a, 2015a) made up of three issues of the Philosophical Transactions from 1665, three issues from 1675, two from 1685, and two from $1694 . .^{1}$ It is perhaps relevant to ask what variety of English is involved. Henry Oldenburg was not a native speaker of English. His mother tongue was German, and he was born in Bremen. However he was a polyglot, and in addition to his native language he knew English, French, Italian, and Dutch, as 
well as Latin and Greek, and perhaps some other languages too. So whether one should consider this a precursor of global English is perhaps a moot point.

\subsection{Framing}

9 Not all of the entries in these issues of the Philosophical Transactions contain story-like features, but many of them do. Consider, for example, this extract from the issue for 6 April 1665 on mercury mines in Friuli. Below is the heading of the item followed by the extract:

1. Extract of a Letter, lately written from Venice by the Learned Doctor Walter Pope, to the Reverend Dean of Rippon, Doctor John Wilkins, concerning the Mines of Mercury in Friuli; and a way of producing Wind by the fall of Water. (3 April 1665)

In going thither, we travell'd several hours in the best Wood I ever saw before or since, being very full of Firrs, Oakes and Beeches of an extraordinary thickness, straitness, and height. [...] When I was there, in August last, the Valley, and the Mountains too, out of which the Mercury was dug, were of as pleasant a verdure, as if it had been in the midst of Spring, which they attribute to the moistness of the Mercury; how truly, I dispute not. That Mine, which we went into, the best and greatest of them all, was dedicated to Saint Barbara [...]. Being at the bottom, we saw no more than what we saw before, only the place whence the Mineral came. ${ }^{2}$

The story-like "feel" of this extract seems to be due mainly to the use of past tense with first-person pronoun subjects, and the use of temporal markers. The information about the woods through which the author passed, and his opinion about the surrounding countryside has virtually nothing to do with the main subject of the article, which is about techniques for mining mercury, and towards the end of the piece, mercury poisoning of the miners. What this extract does is to lead us into the main subject; it thus provides a sort of frame to the article, and I shall call this the Framing Function. It is not without interest that towards the end of the piece the author calls it a "narrative".

2. To give some light to this Narrative, take this Diagramme [...]

11 The frame does not need to be particularly long. The following extract (as before I give first the heading of the item followed by the extract from the piece, and I shall do this for all the extracts from the early issues of the Philosophical Transactions) is taken from the issue for 23 March 1685.

3. Some Observations on Boyling Fountains, and Subterraneous Streams: by Dr. Tancred Robinson, Fellow of the R.S. (23 March 1685)

Walking out one day from Montpellier in company of my ingenious, and worthy friends Dr. Sloan, and Dr. Wakely, in order to visit the famous boyling fountain near Peroul, a small Village lying east about a league from thence, not far from the Etang, I found the water to heave, and boyling up very furiously in small bubbles [...].

12 The details of his walk are not necessary for the discussion of turbulence in these springs, so this constitutes a frame and fulfils a Framing Function, despite the fact that it is relatively short. However, we should note the significance of the presence of reliable witnesses, his "worthy friends". At this period, great importance was placed on having reliable witnesses for phenomena or experiments that were reported. I identified five examples of Framing Function in the sample. 


\subsection{Observation}

Some authors tell us about what they have seen. The following item is taken from the issue for 26 July 1675 . It has a long cumbersome title, and the article which follows is indeed itself a rather rambling affair.

4. Advertisments, occasioned by the Remarks printed in Numb. 114, upon Frosts in some parts of Scotland, differing in their Anniversary Seasons and Force from our ordinary Frosts in England: Of Black Winds and Tempests: Of the warm or fertilizing Temperature and Steams of the surface of the Earth, Stones, Rocks, Springs, Waters, (some in some places, more than other in other places;) of petrifying and Metallizing Waters: With some hints for the Horticulture of Scotland: By the Reverend and Learned Dr. J. Beal, F.R.S.; who by way of Letter imparted them to the Publisher. (26 July 1675)

In the sharpest Frost, that I have known these many years, the ground having been also some daies cover'd with Snow, I saw a small stream (no bigger than might run from the mouth of an ordinary quart Bottle, as now we have them of green Glass) sliding merrily, and smoaking all the way over the lawns: I couldn't discern, that any snow had fallen within five or six foot on each side; if it did, none remained there [...] In a large Tract of Land the surface was so hot a ferment, that at every step I trod up to the ankles. I caused it to be examined by the Spade, and found it as far as I tried here and there, at a foot depth, as thick set with Pibble-stones as if a Causey had been picht here [...].

14 He reports what he observes; he also does things, by having someone dig into the ground with a spade, but the doing is not experimental in the contemporary sense, but simply an aid to observing the phenomenon.

Another interesting example occurs in the issue for 22 August 1685. This is interesting because the observation which is reported is second-hand:

5. An answer to some Quceries proposed by Mr. William Molyneaux, concerning LoughNeagh: by Mr. Edward Smyth, Fellow of Trinity Colledge in Dublin. (22 aug. 1685)

[...] two experiments made by a Gentleman of worth and good credit (whose Estate lies contiguous to the Lough; and whose curiositie prompted him to a more diligent search into this matter) plainly prove the contrary. For about 19 years ago, he stuck two Holly-Stakes (a wood which all agree will soonest petrifie in this Lough) in two severall places of the Lough, near that place where the upper Band enters into it; and that part of the stake, which for so long time has been washed by the water, remains there without any alteration, or the least advance towards petrification; as for that part of the stake which is covered by the mud or earth, he has not yet looked on it, but promises to do it this Summer [...].

Here it is not the author who has observed this phenomenon, but he is reporting a "gentleman of worth and good credit". Although the word "experiments" occurs, the word is used in its seventeenth century rather than its contemporary sense, and the piece is again about observation rather than experimentation. Later in the article we even get a report of third-hand observation:

6. That not only Holly, but also Oak, and some other wood has been petrified about this Lough, and in the soil adjacent, I have sufficient grounds to conjecture on this account; because some Fishermen, being tenants of a gentleman from whom I had this relation, told him, they had found buried in the mud of this Lough great trees, with all their roots and branches petrified; and some of that bigness, that they believ'd they could scarcely be drawn by a teem of Oxen. They broke off severall branches as big as a mans legg, and many bigger, but could not move the great trunk. 
17 Here, the fishermen told the landowner who told the author, hence third-hand observation. I shall call these examples of narrative of observation the Observation Function, and I found six examples of this in the sample.

\subsection{Experiment}

We do find recognizable accounts of experiments in the sample. The following example, from the issue for 22 November 1675, is by the well-known Dutch scientist Christiaan Huygens and his French technician Denis Papin. Papin has a permanent place in the history of technology as the inventor of the pressure cooker (Cabanes 1935). This piece was presumably translated from French by Oldenburg:

7. Some Experiments made in the Air-pump by Monsieur Papin, directed by Monsieur Hugens, (as appeared in the Discourse printed at Paris, 1674.) (22 Nov. 1675)

Whereupon, by means of the Iron-wire, the lesser Glass was let down into the greater, until the Liquors, they contain, did mingle themselves. Thus some Aqua fortis was poured into the upper Glass, and Spirit of Wine into the lower, and the Recipient was so well exhausted of the Air, that the Spirit of Wine boyled up with great bubbles (as usually it doth,) and the Aqua fortis cast some small bubbles. After that both these Liquors were well purged of Air, the upper Glass was sunk into the lower, so as that the Spirit of Wine was mingled with the Aqua fortis; at which instant there was yet seen a very considerable Ebullition.

19 This is quite clearly an experiment (in the modern sense), and this experimental account has a very modern feel with its string of passive verbs. Most of this article is written like this extract, in the passive form, though passages in the active voice do occur:

8. After this, the Experimenter being desirous to see, whether these Ebullitions did make new Air; he put in the Recipient a Gage (that is a glass-tube fill'd either with Water freed of air, or with Mercury, serving to measure the quantity of the Air in the Recipient) which was four Inches long, and observ'd that at the instant when the Liquors were mingled together, the water in the Gage rose very nimbly to the top of the gage; and then drawing out this new Air that was made, he made the gage-water subside again by degrees [...].

Another example of this comes from a piece by van Leeuwenhoek, and which appeared in the issue for 22 August 1685. Like Huygens, van Leeuwenhoek was Dutch, but unlike him, he was an autodidact. Hence, in contrast to most of the other scientists of his day, the only language he knew was his native language, Dutch. This item was therefore presumably translated from Dutch by oldenburg. Van Leeuwenhoek was one of the first microscopists, and is credited with the discovery of spermatozoa (Boutibonnes 1994; Lamendin 2013). The item is a long series of accounts of experiments.

9. An Abstract of a Letter of Mr. Leeuwenhoeck Fellow of the R. Society, dated March $30^{\text {th }}$. 1685. to the R. S. Concerning Generation by an Insect. (22 Aug. 1685)

About the latter end of the Summer of the year 1683. I took the Semen Masculum of a Dog, which was of about a year and half old. This I put into a Glass pipe, and wrapt it up in soft leather, because the nights were something cold. The Semen I observed 4 days successively, and in the first, I found that severall of its Animals were dead. In the $\mathbf{2 d}$ and $\mathbf{3 d}$ day, there were yet more of them dead, but in the 4th, there were very few left alive; and so far I proceeded at that time. But in the beginning of October in the year 1684, I observed again the Semen Masculum of the same Dog, who was then very strong and Vigorous, and I found that after 7 days 
and nights, there were some few Animals yet left alive, a very few whereof swam as

briskly as if they had just come from the Dog.

21 experiments included in this relatively long paper. Here is an example from a different experiment later in the same article (readers who are squeamish may like to skip this one).

10. I bespoke a Bitch of an ordinary size, to be delivered to me after she had been once lined, which hapned to be the $30^{\text {th }}$ of December last, upon the next day at 8 of the clock in the morning, the Bitch was lined again, in my presence, and again at $\mathbf{2}$ a clock in the afternoon, whereupon I caused her to be killed by running an Awl into the Medulla Spinalis near the head. As soon as she was dead, I bound her legs to a Table, and opened the Vagina where I found a white substance, which I took out \& viewed with my Microscope, discovering it to be nothing but Scales (of that sort which cover the inside of the vagina) lying in a clear thin liquid.

I shall say that examples like these fulfil the Experimental Function, and I identified five cases of this in the sample.

\subsection{Third-person stories}

There are some items that include a narrative about a third person. In the following example from the issue for 23 March 1685, we find a short frame followed by a third person account of the progress of that person's illness.

11. A remarkable account of an Hydrophobia, in a letter from $\mathrm{Dr}$ Roger Howman, Physician in Norwich, to William Briggs M. D. Fellow of the Coll. of Phys. Lond. and Physician of St. Tho. Hospitall. (23 March 1685)

On Wednesday at evening the 1. of Octob. last past I was called to a patient in this City, who about 6 weeks before had been bitten with a mad Fox on the right hand; he began to be indisposed the Saturday before with running pains, yet so well as to be abroad next day at Church: on Munday his pains grew more troublesome, and the day following, much worse [...] on Wednesday (I know not by whose advice) he took a dose of the common purging spirit of Scurvy-grass [...].

Here the story is that of the progress of the patient's illness. One can also notice the care taken to establish the time sequence of the development of the illness (Banks 2015b). Another example, from a different item in the same issue, also recounts the progress, and, in this case, the cure of an illness.

12. An Abstract of a Letter from Dr Peirce of Bath, to one of the S. of the R.S. giving an instance of the effects of the Bath in curing the Palsy, and Barenness. (23 March 1895)

A Gentlewoman of about 30 or 32 years of age, having been married about 10 or 13 years, and never with Child, was suddenly seised with a Palsy on the left side; for which after 8 or 10 months trial of other means, to little purpose,) she was brought to the Bath, where (after usual preparations, and some internal means,) she continued that season, about 6 weeks; the winter coming on shee was forced to desist; but (by the advantage shee received,) was encouraged to come very early the next year, and did continue with us the whole summer, and recovered, in great measure, the use of her arm, and hand, leg and tongue; and not only so, but in a few weeks, after shee returned to her husband, conceived with Child, and had (at about a year and halfs distance between them,) 5 children, following.

Here we have the story of a paralyzed woman, who appeared also to be sterile, who underwent treatment at a well-known spa and was cured to the extent that she subsequently bore five children. I shall say that examples like these fulfil a 3rd Person 
Function. This function is less common than the others we have seen, and basically occurs in medical articles, like the two examples above.

Hence, I have identified four possible functions of narration in these late seventeenthcentury texts: Framing, Observation, Experimental and 3rd Person.

\section{The present-day corpus}

I will now fast forward to the present day. The Philosophical Transactions still exists, but in 1997 the Royal Society took the decision that henceforth the contents of the Philosophical Transactions would consist of theme issues, state-of-the-art articles and monographs. Primary research was transferred to the Proceedings of the Royal Society. Hence the Proceedings seems more appropriate for comparison with our seventeenthcentury sample. Moreover for some time now, both the Transactions and the Proceedings have appeared in two separate series. Series A is devoted to mathematical, physical and engineering sciences, while Series B is devoted the biological sciences (Atkinson 1999). This corresponds to a basic distinction between the physical and biological sciences which I pointed out in Banks (2008). I shall therefore deal with Series A and Series B separately.

The Series A sample consists of four articles dated January 2016 and four dated December 2015. The Series B sample contains eight articles, all dated January $2016 .{ }^{1}$

Can this be considered native-speaker English? Although this sort of question was common several years ago, (in the 1980s John Swales developed an algorithm for estimating the likelihood that an author was Anglophone (Swales [1985]), I am not sure that it is still a relevant question, but the following information may be of interest. The eight articles in the Series A sample have two or three co-authors each with a total of twenty co-authors in all. In four cases, all the co-authors, nine in all, give an institutional address in an Anglophone country; this includes one case of two coauthors with an institutional address in India. By the same token, this means that for half of the articles in the sample, none of the co-authors gave an institutional address in an Anglophone country. This is shown in Table 1, where the articles are identified by the first-named author.

Table 1. Proceedings Series A sample

\begin{tabular}{|l|l|l|}
\hline First named author & Co-authors & Anglophone Address \\
\hline 471 (Dec. 2015) & & \\
\hline Azizi & 2 & 0 \\
\hline Lindsay & 3 & 3 \\
\hline Mukherjee & 2 & 2 \\
\hline Vledouts & 3 & 0 \\
\hline 472 (Jan. 2016) & & \\
\hline
\end{tabular}




\begin{tabular}{|l|l|l|}
\hline Adlakha & 2 & 2 \\
\hline Müller & 3 & 0 \\
\hline Rycroft & 2 & 2 \\
\hline Saito & 3 & 0 \\
\hline
\end{tabular}

The situation for Series B is rather more complicated. The articles have between two and ten co-authors, with a total of thirty-four co-authors in all. There is only one article where none of the co-authors gives an Anglophone institutional address. Of the other co-authors, twenty-six give an institutional address in an Anglophone country. This is shown in Table 2.

Table 2. Proceedings Series B sample

\begin{tabular}{|l|l|l|}
\hline First named author & Co-authors & Anglophone Address \\
\hline Giraldo & 10 & 8 \\
\hline Higginson & 3 & 3 \\
\hline Jordan & 4 & 3 \\
\hline Schlüter & 3 & 2 \\
\hline Pigot & 3 & 3 \\
\hline Steidinger & 2 & 2 \\
\hline Van Houten & 5 & 5 \\
\hline Viana & 4 & 0 \\
\hline
\end{tabular}

31 However this simple information is to some extent misleading. Against it must be laid the fact that a number of authors give multiple addresses: eight of the co-authors give two addresses, and two of them give three! Hence the extent to which an Anglophone institutional address might be taken as implying an Anglophone author is greatly diminished. Moreover, we do not know whether the article was drafted by one or more of the co-authors, whether different co-authors drafted different parts of the article, whether it was corrected by a native speaker, or whether it was translated from a nonEnglish original.

In addition, it should be noted that the time lapse between reception and acceptance is relatively short, between one and seven months in the case of Series A, and only one or two months in the case of Series B. And I must admit that I came across some examples which I would have considered at least doubtful, if not unacceptable, in my native variety. At all events, these articles were found acceptable and were published in a prestigious journal. 


\subsection{Series A Niche}

I shall deal first with the Series A articles. In some of these we find a narrative which tells "the story so far", almost like the summary one finds of previous episodes in a serialized magazine story. This may be in the form of a literature review.

13. Several criteria [...] have been developed to predict the outcome for the DGB interaction. Shen et al. [...] devised a set of rules to predict the slip transmission when: (i) the angle of intersection between both the incoming and outgoing slip plane is minimized and (ii) the resolved shear stress acting along the slip direction is maximized. Further, based on in situ TEM experiment, Lee et al. [...] proposed an additional criterion to the model of Shen et al. [...] that ensures the outcome of slip transmission is based on the minimum residual dislocation along the GB, also known as the Lee-Robertson-Birnbaum (LBR) criteria. (Adlakha \& Solanki, Proceedings A, 472)

However, some examples are not strictly speaking a literature review. This example tells us of the authors' own previous work which led up to the present contribution.

14. Previously, we introduced a very powerful Brownian dynamics finite-element method for the simulation of cross-linked biopolymer networks where filaments and linker molecules are modeled with geometrically exact, nonlinear simeReissner beam finite elements [...]. We also discussed methodic extension that decouple the chemical topology of the filaments from their mechanical discretization [...]. Thereby we laid the foundation for the present contribution, in which a computational model of a non-processive molecular motor is motivated, discussed and numerically evaluated. (Müller et al., Proceedings A 472)

Since this is justifying the article in terms of what has been done in the past, I shall, following Swales $(1990,2004)$, call this the Niche Function. I found this in five of the eight Series A articles.

\subsection{Series A Preview}

In some articles we find a story which is a summary of the narrative which will be recounted at greater length in what follows, a summary, as it were, of what will happen later.

15. The paper proceeds as follows. In \$2, we present the theoretical background of the model and derive an evolution equation for the shape of a dissolving body in terms of a time-dependent conformal map from the unit circle to the physical domain, described by a Laurent series. In \$3, we then derive a system of ordinary differential equations that govern how the Laurent series coefficients evolve with time. We numerically integrate this system using an eighth-order time-stepping method [...] which allows the dissolution process to be simulated very accurately, close to the limit of machine precision. (Rycroft \& Bazant, Proceedings A, 472)

I shall call this the Preview Function; this is less common and occurs in two of the eight articles.

\subsection{Series A Experiment}

Those articles which involve an experiment have an account of the experiment, which is a form of narrative. 
16. The cyanidation experiments were carried out in a tumble bottle at ambient temperature under different conditions including $\mathrm{pH}$ of 10-11.5, solids content of $30-45 \%$, sodium cyanide concentration of 500-900 ppm, particle size of 37-100 $\mu \mathrm{m}$. For each test, a $300 \mathrm{~g}$ representative sample was selected. First, the pulp was prepared in the tumble bottle and the $\mathrm{pH}$ was adjusted using $\mathrm{Ca}(\mathrm{OH})_{2}$ to the targeted value, then the sodium cyanide (prepared by Merck \& Co.) was added to the pulp and the pulp was mixed. There were some holes in the bottle cap to aerate the pulp. After each experiment, the sample was filtered and the liquid phase was analysed for the gold content and free cyanide. (Azizi \& Ghaedrahman, Proceedings A, 471)

\section{Series B}

\subsection{Series B Niche}

Turning to the Series B articles, all four functions were found to some extent. The Niche Function was present in five of the Series B articles, the same rate as in Series A.

18. Theoretical and empirical research has long been concerned with finding ways to overcome social dilemmas in natural resource use that arise when the individual short-term benefits from resource exploitation lead users to collectively overharvest [...]. While early research emphasized the need for government control or privatization [...] recent empirical work has highlighted that communities are often capable of overcoming the dilemma and achieve sustainable resource use through cooperative self-governance [...]. Different mechanisms have been proposed for successful self-governance, such as communication, monitoring and sanctioning [...] or reciprocity [...]. Ostrom [...] and others [...] have found that successful communities often establish social norms (i.e. 'rule(s) or standard(s) of 
behavior shared by members of a social group' [...]) to discourage individual overharvesting. (Schlüter et al., Proceedings B, 283) following example starts from Darwin.

19. Since Darwin [...] migratory birds have been suggested to be involved in the LDD of a variety of organisms, mainly in aquatic ecosystems, where both epi- and endo-zoochory are frequent [...]. Other long-distance fliers, such as seabirds, have been proposed as vectors as vectors of LDD between oceanic islands [...]. However, at present, there is only indirect evidence of the potential of migratory birds as LDD vectors, which is derived from phylo- and biogeographic patterns and anecdotal observations of seeds in the gut or plumage of migratory birds before or after active migration [...]. (Viana et al., Proceedings B, 283)

\subsection{Series B Preview}

The Preview Function also occurs in the Series B articles at the same rate as in the Series A, two out of eight.

20. We searched, collected and quantified seeds from hunted migratory birds to investigate whether overseas migratory movements of birds can mediate seed LDD. For this purpose we used the 'sampling services' provided by the hunting activity of a wild population of Eleonora's falcons (Falco eleonorae) and last-generation tracking technology [...]. By analyzing falcon movements and identifying seeds, we could safely conclude that seeds were carried from overseas locations and not ingested locally. (Viana et al., Proceedings B, 283)

\subsection{Series B Experiment}

The Experimental Function occurs at virtually the same rate as in Series A, five out of eight, as compared with four out of eight in Series A.

21. We mounted polished PM cross-sections onto glass slides using fine mesh double-stick tape. Similar to previous studies [...] we drilled a 1 x $10 \mathrm{~mm}$ linear path along growth line contours to $1 \mathrm{~mm}$ depth (just shy of specimen thickness). We repeatedly scanned the same paths at overlapping approximately $250 \mu \mathrm{m}$ depths to obtain 1-3 mg of powder. We sampled the outermost and intermediary growth zones as feasible. (Van Houten et al., Proceedings B 283)

Perhaps surprisingly, two of the five articles concerned told the story of the experiment using active verbs extensively. In view of the vast literature on the use of the passive voice in scientific writing from Barber's seminal article (1962) onwards, and including the well-known work on the subject by Tarone et al. $(1981,1998)$, and despite the fact that some have recently claimed to have detected a change in the use of passive voice in scientific writing (Seoane 2006), this is an interesting feature. Moreover, it can be noted that whereas the sections using the Experimental Function in the Series A articles tended to be fairly short, those in the Series B articles, particularly those using the active voice were relatively long stretching over several pages.

One article written basically in the active voice included a section in the passive before moving back to the active voice.

22. We constructed separate networks for four different interactions types; [...] We analysed whole network autocorrelation patterns across time, correlating all consecutive days of each network to calculate product moment correlation coefficients of the network adjacency matrices. We then assessed the significance of these coefficients [...]. 
Experimental groups were chosen to contain a single male and either one or two adult females [...]. Prior to manipulation, experimental groups were selected and identified by placing small pieces of flat stone marked with treatment number adjacent to the nest depression. [...] The location of groups was tracked by recording digital video on line transects [...]

We calculated the change by subtracting the number of individuals present in the past observation from the number observed in the first observation. We used Bayesian linear models with treatment as a fixed factor and post hoc testing here appropriate on the same nine planned contrasts described above. (Jordan et al., Proceedings B, 283)

Another, written mainly in the passive, switched to the active half way through.

23. Nursing ability was assayed in a cylindrical chamber (34 $\mathrm{mm}$ inner diameter) with a humidified plaster-like bottom (dental stone) to prevent larvae from desiccating. Sides were coated with Fluon to prevent escape. Eight $2^{\text {nd }}$ to $4^{\text {th }}$ instar larvae with dark guts were added to the chamber and evenly distributed along the circumference of a $20 \mathrm{~mm}$ circle.

We used standardized effect sizes to estimate the power of our analyses, and hence our ability to detect significance. For TUNEL analysis, we calculated power using a simulation method for an effect size of 0.5 as well as 2.5 , which we found between brain regions. (Giraldo et al., Proceedings B, 283)

There was a further article which constantly switched back and forth between active and passive voice. This is obviously a point which merits further study.

\subsection{Series B Recap}

51 The Recap Function was found in only one of the Series B articles, compared to five in Series A, so it would seem to be rare in Series B.

24. In this study, we examined the social and ecological sources of selection acting on an extended phenotype in the wild. By producing an 'over-extended' phenotype - the shell nest of the cichid N. multifasciatus - we found evidence for positive sexual selection, in the form of increased access to mates, acting on augmented extended phenotypes [...]. Although we also found some evidence that territory augmentation leads to extra males joining these groups [...] the evidence was weak and only suggestive of a potential cost in the form of paternity loss to additional males. (Jordan et al., Proceedings B, 283)

There was one article in the sample which had none of the four functions.

\section{Present tense stories?}

The story-telling features that we have identified usually involve some form of past tense, most commonly the simple past, but occasionally the present perfect, particularly in the Niche and Recap Functions. Consequently, it seems worthwhile asking whether a present tense story is possible. In literature the use of present tense has become relatively common in the course of the twentieth century, though perhaps rather more so in French than in English. Consider the following example.

25. Here, we contrast three qualitatively different ways this can occur, designating as linear, saturating and accelerating functions, respectively [...]. We assume that there is no difference in allocation to mutualists and exploiters within a module, which is supported empirically in the fig-wasp symbiosis [...]. Thus when $\alpha=0.50$, we have a linear function where host allocation increases steadily with the proportion of mutualists within a module. (Steidinger \& Bever, Proceedings B 283) 
54

present tense verbs of this extract were replaced by past tense verbs, I feel that that would give it a story-like "feel". As it is, my reading suggests that the present tense verbs take it outside of the story-telling category. However, there is one of the above examples which does use present tense verbs. This is example 15, which illustrates the Preview Function in a Series A article. This is a case of simple present tense with future reference, at least, future from the reader's point of view, since he has not read it yet. So I would suggest that present tense is not a marker of story-telling in this genre, except in the case of the Preview Function where it refers to things which will be recounted later in the article.

\section{Closing comments}

We have identified four functions of story-telling in present-day scientific research articles; Niche, Preview and Experimental occur at roughly the same rate in our Series A and Series B articles; Recap is more common in Series A than in Series B. However, there are two important provisos to be made. First, this study uses a small sample, and while the results are coherent, and thus constitute useful working hypotheses, they remain subject to confirmation by future research on a larger corpus. Moreover the sample makes a generic distinction between articles in the physical sciences (Series A), and those in the biological sciences (Series B). It is probable that finer generic distinctions within these categories would show further differences between those subgenres. Biber and Gray (2013) have warned against the dangers of underestimating the effects of subregister differences. Secondly, it must be noted that these functions are not clear-cut categories with clearly-defined watertight boundaries; on the contrary they are fairly fuzzy categories that fade out at the edges and can overlap with other features.

When these four functions are compared with the four functions found in the late seventeenth century, it is immediately seen that only Experimental is common to both periods. A possible exception is the 3 rd person Function. In the 17 th century sample, it occurs in articles of a medical nature. Although it does not occur in the present-day sample, the Philosophical Transactions articles do not include medical research. Only further study will show whether this function occurs in contemporary medical research articles. Intuitively it would seem possible that it might occur, in medical research particularly in articles of the case study type. The functions found in this corpus are shown in Table 3.

Table 3. Functions for both corpora

\begin{tabular}{|l|l|l|l|}
\hline Late $\mathbf{1 7}^{\text {th }}$ century & Framing & Present-day & Niche \\
\hline & Observation & & Preview \\
\hline & Experimental & & Experimental \\
\hline & 3rd person & & Recap \\
\hline
\end{tabular}



mathematical modelling became popular and accounted for a fair proportion of articles in the physical sector from then on. The biological sector continued to be experimental, and even in some cases observational, until the late twentieth century. There is now some evidence that mathematical modelling has entered the biological field since about 1980. My hunch is that storytelling features will tend to be found in articles of an experimental type rather than in those of the mathematical modelling type. These hunches indicate two of the many possible future lines of enquiry, and show that this area of study could be a fruitful field for future research.

I would like to thank two anonymous ASp reviewers for their helpful remarks which have enabled me to improve this article. However, it goes without saying that only I am responsible for any shortcomings which remain. 


\section{BIBLIOGRAPHY}

ATKINSON, Dwight. 1999. Scientific Discourse in Sociohistorical Context. The Philosophical Transactions of the Royal Society of London, 1665-1975. Mahwah, N.J.: Lawrence Erlbaum Associates.

BANKS, David. 2005a. "The case of Perrin and Thomson: An example of the use of a mini-corpus".

English for Specific Purposes 24/2, 201-211.

BANKS, David. 2005b. Introduction à la linguistique systémique fonctionnelle de l'anglais. Paris:

L'Harmattan.

BANKS, David. 2008. The Development of Scientific Writing, Linguistic features and historical context. London: Equinox.

BANKS, David. 2015a. "Compter et mesurer dans le texte scientifique de la fin du dix-septième siècle”. In BANKS, D. (ed.), La quantification dans le texte de spécialité. Paris: L’Harmattan, 7-27. BANKS, David. 2015b. "Approaching the Journal des Sçavans, 1665-1695: a manual analysis of thematic structure". Journal of World Languages 2/1, 1-17. <http://www.tandfonline.com/doi/ful/ 10.1080/21698252.2015.1010248\#abstract>

BANKS, David. In press. The Birth of the Academic Article. Le Journal des Sçavans and the Philosophical Transactions, 1665-1700. Sheffield: Equinox.

BARBER, C.L. 1962. "Some measureable characteristics of modern scientific prose". In BEHRE, F. (ed.), Contributions to English Syntax and Philology. Stockholm: Almqvist \& Wiksell, 21-43.

BARTHES, Roland. 1966. “Introduction à l'analyse structural des récits”. Communications 8, 1-27.

BARTHES, Roland. 1977. Image Music Text (translated by Stephen Heath). London: Fontana.

BIBER, Douglas \& BETHANY GRAY. 2013. "Being specific about historical change: the influence of subregister". Journal of English Linguistics 41/2, 104-134.

BLUHM, R.K. 1960. “Henry Oldenburg, F.R.S. (c.1615-1677)”. In Hartley, H. (ed.), The Royal Society. Its origins and founders. London: The Royal Society, 47-56.

BOUTIBONNES, Philippe. 1994. Antoni van Leeuwenhoek, 1632-1723. L'exercice du regard. Paris: Belin. CABANES, Charles. 1935. Denys Papin, Inventeur \& philosophe cosmopolite. Paris: Société Française d'Éditions Littéraires et Techniques.

CLARK, George. 1956. The Later Stuarts, 1660-1714, $2^{\text {nd }}$ edn. Oxford: Oxford University Press. CZARNIAWSKA-JOERGES, Barbara. 1995. "Narration or science? Collapsing the division in organization studies". Organization 2/1, 11-33.

GIGNOUX, C.-J. 1941. Monsieur Colbert. Paris: Grasset.

GROBSTEIN, Paul. 2005. "Revisiting science in culture: science as story telling and story revising". Journal of Research Practice 1/1, retrieved from <http://jrp.icaap.org/ index.php/jrp/article/view/ 9/18> on 3 July 2016.

GOTTI, Maurizio. 2006. "Disseminating early modern science: specialized news discourse in the Philosophical Transactions". In BRownLEES, N. (ed.), News Discourse in Early Modern Britain. Bern: Peter Lang, 41-70. 
GOTTI, Maurizio. 2011. “The development of specialized discourse in the Philosophical Transactions". In TAAVITSAINEN, I. \& P. PAHTA (eds.), Medical Writing in Early Modern English. Cambridge: Cambridge University Press, 204-220.

GROSS, Alan G., Joseph E. HARMON \& Michael REIDY. 2002. Communicating Science. The scientific article from the 17th century to the present. Oxford: Oxford University Press.

HAHN, Roger. 1971. The Anatomy of a Scientific Institution, the Paris Academy of Sciences, 1666-1803. Berkeley: University of California Press.

HALL, Marie Boas. 2002. Henry Oldenburg, Shaping the Royal Society. Oxford: Oxford University Press. HALLIDAY, M.A.K. 2014. Halliday's Introduction to Functional Grammar, 4th. edn. (revised by Christian M.I.M. MATTHIESSEN). London: Routledge.

HALLIDAY, M.A.K. \& J.R. MARTIN. 1993. Writing Science. Literacy and discursive power. London: Falmer Press.

HILL, Christopher 1969 [1961]. The Century of Revolution, 1603-1714. London: Sphere Books.

HIRSCHFIELD, John Milton. 1981. The Académie Royale des Sciences 1666-1683. New York: Arno Press.

KISHLANSKY, Mark. 1996. A Monarchy Transformed. Britain 1603-1714. London: Penguin.

KRONICK, David A. 1962. A History of Scientific and Technical Periodicals. The origins and development of the scientific and technological press 1665-1790. New York: Scarecrow Press.

KRONICK, David A. 1991. Scientific and Technical Periodicals of the Seventeenth and Eighteenth centuries: A guide. Metuchen, N.J.: Scarecrow Press.

KUUKKANEN, Jouni-Matti. 2012. "The missing narrativeist turn in the historiography of science”. History and Theory 51, 340-363.

LAMENDIN, Henri. 2013. Antoni van Leeuwenhoek (1632-1723). Le microscope médical et mes spermatozoïdes. Paris: L'Harmattan.

LEWIN, Beverley A., Jonathan FINE \& Lynne YounG. 2001. Expository Discourse. A genre-based approach to science texts. London: Continuum.

LICOPPE, Christian. 1994. "The crystallization of a new narrative form in experimental reports (1660-1690). The experimental evidence as a transaction between philosophical knowledge and aristocratic power". Science in Context 7/2, 205-244.

LICOPPE, Christian. 1996. La formation de la pratique scientifique. Le discours de l'expérience en France et en Angleterre (1630-1820). Paris: La Découverte.

LYONS, Henry. 1944. The Royal Society 1660-1940. A history of its administration under its charters. Cambridge: Cambridge University Press.

MCCLELLAN III, James E. 2001. “The Mémoires de l'Académie Royale des Sciences, 1699-1790: A statistical overview". In HALLEUX, R., J. MCCLELLAN, D. BERARIU \& G. XHAYET (eds.). Les publications de l'Académie Royale des Sciences de Paris (1666-1793), Vol 2. Turnhout: Brepols, 7-36.

MORGAN, Betty Trebelle. 1928. Histoire du Journal des Sçavans depuis 1665 jusqu'en 1701. Paris: Presses Universitaires de France.

MYERS, Greg. 1990. Writing Biology. Texts in the social construction of scientific knowledge. Madison, WI: University of Wisconsin Press. 
OAKLEY, RODD. 2005. "Implied narratives of medical practice in learning-for-doing texts: a simulation semantics approach to rhetorical analysis“. Language and literature 14, 295-310.

SEOANE, Elena. 2006. "Changing styles: On the recent evolution of scientific British and American English". In DALTON-PUFFER, C., D. KASTOVSKY, N. RITT \& H. SCHENDL (eds.), Syntax and Grammatical Norms: English from 1500-2000. Bern: Peter Lang, 191-209.

SOLLACI, Lucinda B. \& Mauricio C. PEREIRA. 2004. "The introduction, methods, results, and discussion (IMRAD) structure: a fifty-year survey". Journal of the Medical Library Association 92/3, 364-367.

SWALES, J.M. 1985. "English language papers and author's first language: Preliminary explorations". Scientometrics 8/1-2, 91-101.

SWALES, John M. 1990. Genre Analysis, English in academic and research settings. Cambridge: Cambridge University Press.

SWALES, John M. 2004. Research Genres, Exploration and applications. Cambridge: Cambridge University Press.

TARONE, Elaine, Sharon DWYER, Susan Gillette \& Vincent ICKE. 1981. "On the use of the passive in two astrophysics journal papers". ESP Journal 1/2, 121-139.

TARONE, Elaine, Sharon DWYER, Susan Gillette \& Vincent ICKE. 1998. "On the use of passive and active voice in astrophysics journal papers: With extensions to other language and other fields". English for Specific Purposes 17/1, 113-132.

THOMPSON, Susan. 2002. “'As the story unfolds': the uses of narrative in research presentations”. In VENTOLA, E., C. SHALOM \& S. THOMPSON (eds.), The Language of Conferencing. Frankfurt am Main: Peter Lang, 147-167.

\section{APPENDIXES}

\section{Appendix 1 - Sub-areas of present-day corpus}




\begin{tabular}{|l|l|}
\hline Philosophical Transactions A & Mechanical engineering \\
Applied mathematics & Mechanics \\
Atomic and molecular physics & Statistical physics \\
Biomechanics & Statistics \\
Chemical engineering & Structural engineering \\
Chemical physics & Philosophical Transactions B \\
Computational mathematics & Behaviour \\
Computational mechanics & Ecology \\
Computer modelling and simulation & Environmental science \\
Differential equations & Evolution \\
Fluid mechanics & Health and disease and epidemiology \\
Materials science & Neuroscience \\
Mathematical modelling & Theoretical biology \\
\hline
\end{tabular}

\section{Appendix 2 - Seventeenth century corpus}

\begin{tabular}{|l|l|}
\hline & 3 April 1665 \\
5 June 1665 \\
4 December 1665 \\
Philosophical Transactions & 22 February 1675 \\
& 23 Maly 1675 \\
& 22 August 1685 1685 \\
& March/April 1694 \\
& July/August 1694 \\
\hline
\end{tabular}

\section{Appendix 3 - Present-day corpus}

Proceedings of the Royal Society A, 471 (Dec. 2015)

Mukherjee \& Ghose, Deviated linear cyclic pursuit

Azizi \& Ghaedrahmati, Optimizing and evaluating the operational factors affecting the cyanide leaching circuit of the Aghdarej gold processing plant using a CCD model

Vledouts et al., Fragmentation as an aggregation process

Lindsay et al., Vibrations of thin plates with small clamped patches

Proceedings of the Royal Society A, 472 (Jan. 2016)

Adlakha \& Solanki, Critical assessments of hydrogen effects on the slip transmission across grain boundaries in $\alpha-\mathrm{Fe}$ 
Müller et al., Beam finite-element model of a molecular motor for the simulation of active fibre networks

Rycroft \& Bazant, Asymmatric collapse by dissolution or melting in a uniform flow

Saito et al., Designing of self-deploying origami structures using geometrically misaligned crease patterns

Proceedings of the Royal Society B, 283 (Jan. 2016)

Giraldo et al., Lifespan behavioural and neural resilience in a social insect

Steidinger \& Bever, Host discrimination in modular mutualisms: a theoretical framework for mete-populations of mutualists and exploiters

Jordan et al., The social and ecological costs of an 'over-extended' phenotype.

Schülter et al., Robustness of norm-driven cooperation in the commons.

Higginson et al., Fatness and fitness: exposing the logic of evolutionary explanations for obesity

Viana et al., Overseas seed dispersal by migratory birds

Pigot et al., Functional traits reveal the expansion and packing of ecological niche space underlying an elevational diversity gradient in passerine birds

Van Houtan et al., Time in tortoiseshell: a bomb radiocarbon-validated chronology in sea turtle scutes

\section{NOTES}

1. An earlier version of this paper was given at the 37th International GERAS Conference, "Mapping the narrative and poetic margins of English for Specific Purposes", Université Paris 8, 17-19 March 2016.

2. Details of sub-areas covered, given as "subject areas" on the first page of each article, are listed in Appendix 1.

1. Full details are given in Appendix 2 .

2. Relevant segments of examples are printed in bold. Otherwise the original spelling and typography have been retained, with the exception of "long s", which has been replaced by a modern "s".

1. Full details are given in Appendix 3.

1. However, I have been told (Peter Follette, personal communication), that story-like features can be found in the Results sections of articles in molecular biology.

\section{ABSTRACTS}

The object of this paper is to see to what extent story-telling techniques are used in the scientific research article at two points in time: the late seventeenth century when the first scientific 
articles appeared, and the present day. For the late seventeenth century, the corpus consists of ten issues of the Philosophical Transactions from the period 1665 to 1694. Story-telling in these texts fulfils one of four functions: Framing, Observation, Experimental and $3^{\text {rd }}$ Person. The present day corpus consists of eight articles from Series A and eight articles from Series B of the Proceedings of the Royal Society for the years 2015-2016. Story-telling in these texts again fulfils one of four functions: Niche, Preview, Experimental and Recap. Only the Experimental Function has survived over the period between the two subcorpora. Among other points of interest is the use of active voice in the Experimental Function of Series B articles, but not in Series A.

Le but de cet article est de considérer à quel point les techniques de narration sont utilisées dans l'article de recherche scientifique. L'auteur se penche sur deux périodes historiques : la deuxième moitié du dix-septième siècle, qui a vu la naissance de l'article scientifique, et la période actuelle. Le corpus du dix-septième siècle comporte dix numéros des Philosophical Transactions pour la période 1665 à 1694. Dans ces textes, la narration correspond à l'une de quatre fonctions: Cadrage, Observation, Expérimentation et $3^{\mathrm{e}}$ Personne. Le corpus du vingt-et-unième siècle comporte huit articles de la Séries A et huit articles de la Séries B des Proceedings of the Royal Society pour les années 2015 et 2016. Dans ces textes, la narration correspond aussi à l'une des quatre fonctions: Niche, Aperçu, Expérimentation et Récapitulation. La Fonction d'Expérimentation est la seule d'avoir survécu d'une période à l'autre. Parmi d'autres points d'intérêt se trouve l'usage de la voix active dans la Fonction Expérimentation dans les articles de la Séries B, mais pas dans ceux de la Séries A.

\section{INDEX}

Mots-clés: article de recherche, discours scientifique, narration, voix active, voix passive Keywords: active voice, passive voice, scientific discourse, story-telling, research article

\section{AUTHOR}

\section{DAVID BANKS}

David Banks is Emeritus Professor at the Université de Bretagne Occidentale. He is former Head of the English Department, Director of ERLA and Chairman of AFLSF. He is author or editor of thirty books and has published 100 academic articles. His book, The Development of Scientific English, Linguistic features and historical context (Equinox), won the ESSE Language and Linguistics book award 2010. David.Banks@univ-brest.fr 